\title{
Plant growth regulators on sweet sorghum: physiological and nutritional value analysis
}

\author{
'Federal University of Viçosa, Rio Paranaíba, MG, Brazil. \\ ${ }^{2}$ São Paulo University, Piracicaba, SP, Brazil. \\ ${ }^{3}$ São Paulo University, Ribeirão Preto, SP, Brazil. \\ *Corresponding author, e-mail: wrmacedo@ufv.br
}

Willian Rodrigues Macedo'*, Diego Kitahara Araújo², Valdinei Moreira Santos², Paulo Roberto de Camargo e Castro², Gisele Machado Fernandes ${ }^{3}$

\begin{abstract}
Sweet sorghum has gained attention in tropical and subtropical regions because of its potential as a bioenergy crop. The present research was carried out to evaluate the physiological, biochemical and nutritional characteristics of sweet sorghum submitted to six plant growth regulators (thiamethoxam, biostimulant mixture, gibberellic acid, chlormequat chloride, ethephon, and trinexapac-ethyl). The compounds were applied via foliar spraying in order to increase the productive potential of plants and reduce the carbohydrates sink strength by inflorescences. The experiment was conducted in pots and the following variables were evaluated: plant height, inflorescence dry matter, soluble solids content, shoot dry matter, crude protein, ashes, neutral detergent fiber and in vitro digestibility. It were observed the action of trinexapac-ethyl and ethephon to reduce the inflorescence dry matter, chlormequat chloride to increase the shoot dry matter, and trinexapac-ethyl to improve ashes content and reduce the neutral detergent fiber contents. These results indicate that chlormequat chloride and trinexapacethyl are effective in restricting the plant growth and increasing sorghum nutritional quality.
\end{abstract}

Keywords: Sorghum bicolor, plant growth, plant nutritional quality, bioenergy

\section{Reguladores vegetais em sorgo sacarino: análises fisiológicas e de qualidade nutricional}

\section{Resumo}

O sorgo sacarino tem ganhado atenção em regiões tropicais e subtropicais devido ao seu potencial uso como cultivo bioenergético. Nosso estudo avaliou as características fisiológicas, bioquímicas e nutricionais do sorgo sacarino submetido a seis reguladores vegetais (thiamethoxam, mistura bioestimulante, ácido giberélico, cloreto de clormequat, etefon e etil-trinexapac). Os compostos foram aplicados via pulverização foliar, no intuito de avaliar o potencial aumento na produção das plantas, bem como reduzir a força do dreno de carboidratos promovida pelas inflorescências. O experimento foi conduzido em vasos, onde avaliaram-se as seguintes variáveis: altura de planta, massa seca das inflorescências, conteúdo de sólidos solúveis, massa seca da parte aérea, proteína bruta, cinzas, fibra em detergente neutro e digestibilidade in vitro. Entre os reguladores de crescimento testados, foi observada a ação do etil-trinexapac e do etefon na redução da matéria seca da inflorescência, do cloreto de clormequat no ganho de matéria seca da parte aérea e do etil-trinexapac para incrementar o teor de cinzas e reduzir a fibra em detergente neutro. Estes resultados indicam que o cloreto de clormequat e o etil-trinexapac são eficazes na restrição do crescimento e melhoria da qualidade nutricional do sorgo.

Palavras chave: Sorghum bicolor, crescimento vegetal, qualidade nutricional, bioenergia 
Sweet sorghum (Sorghum bicolor (L.) Moench) is gaining prominence in many countries as an alternative for biofuel production (Godsey et al., 2012) due to its high production of lignocellulosic biomass and fermentable sugars (Whitfield et al., 2012). A great advantage of sweet sorghum is its optimization of use. This crop is the fifth most cultivated cereal around the world and is grown for ethanol production, forage, sugar, grain and fiber purposes (Yuan et al., 2008).

As a dynamic crop, it is necessary to adapt farming practices to improve its technological quality. Getting shorter plants is a tendency for this crop, aiming to facilitate the mechanized harvest, because excess of growth favors the plant lodging, affecting negatively the harvest (Rademacher, 2000). Reducing the size of inflorescence is also interesting because the inflorescences are characterized as a strong sink for carbohydrates (Milne et al., 2013), which limits the ethanol production due to less sugars stored in stalks.

The application of plant growth regulators (PGRs) can be useful not only to achieve the technological quality desired by the ethanol industry (Almodares et al., 2013), but the quality needed for other purposes as forage, for example. PGRs are compounds able to change the morphology and physiology of plants and can be applied at different times (Leite et al., 2011), depending on the grower purpose for the crop. The objective of the study was investigating the effect of PGRs on physiological and nutritional quality of sweet sorghum.

The experiment was conducted at "Luiz de Queiroz" College of Agriculture, University of São Paulo, Piracicaba, São Paulo, Brazil, $\left(22^{\circ} 42^{\prime}\right.$ $S$ and $47^{\circ} 38^{\prime}$ W) using $20 \mathrm{dm}^{3}$ pots. The pots were filled with a substrate composed of clay, silt, and sand at the ratio $267: 113: 620 \mathrm{~g} \mathrm{~kg}^{-1}$, with the following chemical characteristics: $\mathrm{pHCaCl}_{2}=5.0$, organic matter $=14.0 \mathrm{~g} \mathrm{dm}^{-3}, \mathrm{P}=2.9 \mathrm{mmol} \mathrm{dm}^{-3}$, $\mathrm{K}=1.4 \mathrm{mmol} \mathrm{dm}^{-3}, \mathrm{Ca}=42 \mathrm{mmol} \mathrm{dm}^{-3}$, and $\mathrm{Mg}=$ $7 \mathrm{mmol} \mathrm{dm}^{-3}$. Each pot received, approximately, $10.5 \mathrm{~g}$ of the fertilizer N-P-K, at the ratio 4:14:8. Pots were maintained in an open environment with an average temperature of $24.8^{\circ} \mathrm{C}$ and rainfall of $106.3 \mathrm{~mm}$ during the experiment.
The sowing was carried out on December, 2011 and the harvest on March, 2012. Ten sorghum, cv. Ceres 81, seeds were sowed in each pot, thinned after 14 days, maintaining two plants for subsequent treatments. The experimental design used was the completely randomized plots with the application of seven treatments in six repetitions, totaling 42 pots.

The treatments consisted of foliar spraying, with hand-held sprayer (300 KPa): $\mathrm{Tl}$ water (control), T2 - thiamethoxam (125 $\mathrm{mg} \mathrm{L}^{-1}$ ), T3 - biostimulant mixture $10.5 \mathrm{mg} \mathrm{L}^{-1}$ gibberellic acid + $0.5 \mathrm{mg} \mathrm{L}^{-1}$ indol-3-butiric acid $+0.9 \mathrm{mg}$ $\mathrm{L}^{-1}$ kinetin), T4 - gibberellic acid (50 $\left.\mathrm{mg} \mathrm{L}^{-1}\right), \mathrm{T} 5$ chlormequat chloride (100 $\left.\mathrm{mg} \mathrm{L}^{-1}\right), \mathrm{T} 6$ - ethephon (800 $\mathrm{mg} \mathrm{L}^{-1}$ ), and $\mathrm{T7}$ - trinexapac-ethyl $(750 \mathrm{mg}$ $\left.\mathrm{L}^{-1}\right)$. The treatments were performed with 14-day intervals, starting at 23 days after sowing (DAS), when were applied T2, T3, and T5. At 37 DAS T2, T3, T4, and T5 were applied. At 51 DAS, were applied T2, T3, T4, T5, T6, and T7. Lastly, at 65 DAS, we repeated the application of $\mathrm{T} 2, \mathrm{~T} 3, \mathrm{~T} 4, \mathrm{~T} 5, \mathrm{~T} 6$, and T7.

Measurements of plant height (PH) were taken from the soil surface to the ligule of the last fully expanded leaf, starting at 7 DAS and repeated at seven-day intervals until the appearance of the flag leaf. At 86 DAS, the plants were harvested to evaluate the soluble solids (SS) content, pressing the first internodes of the plant base to obtain the juice. The juice was put on a digital refractometer (PR-101 ${ }^{\oplus}$, ATAGO Co., Japan) which expresses results as ${ }^{\circ}$ Brix. Plants were separated into shoots (stalks and leaves) and panicles, then put into kraft paper bags and dried at $65^{\circ} \mathrm{C}\left( \pm 2{ }^{\circ} \mathrm{C}\right)$ for $72 \mathrm{~h}$ to obtain data of shoot dry matter (SDM) and inflorescence dry matter (IDM), respectively.

After assessments of dry matter (DM) variables, three replicates of each treatment were used for chemical analysis. Crude protein (CP) and ashes content were determined according to the methodology of the AOAC (1995), while the neutral detergent fiber (NDF) was assessed following the method proposed by Van Soest (1994). These variables were expressed as grams per kilogram of total DM. The evaluation of the in vitro digestibility (IVD) was performed according to the method proposed by Tilley \& 
Terry (1963).

The results were submitted to variance analysis (ANOVA) and the means of significantly different variables were submitted to the means comparison analysis by the Tukey's multiple range test, using the statistical package SAS 9.2 (SAS, 2009).

It was evident that the responses in plant growth were influenced by PGRs. Differences in $\mathrm{PH}$ have been observed from 49 DAS, where the use of trinexapac-ethyl and ethephon reduced strongly $\mathrm{PH}$ by $46 \%$ and $26 \%$, respectively, compared to control (Figure 1), as well as they reduced the IDM, by $35 \%$ and $61 \%$, respectively (Table 1). In contrast to these products, the use of gibberellic acid increased IDM by $9 \%$ over the control (Table 1).

Trinexapac-ethyl is a substance belonging to the acylcyclohexanediones group, which blocks the conversion of inactive precursors into highly active gibberellins forms, inhibiting the final steps of gibberellin biosynthesis pathway (Rademacher, 2000). As a plant growth inhibitor, trinexapac-ethyl application results in reduced shoot growth virtually in all higher plants (Nakayama et al., 1991). It was observed this effect in the present experiment by either $\mathrm{PH}$ (Figure 1) or IDM (Table 1) reduction. The reduction of $\mathrm{PH}$ is a desirable factor because it reduces plant lodging, improving the harvest performance, besides the increase in plant density.

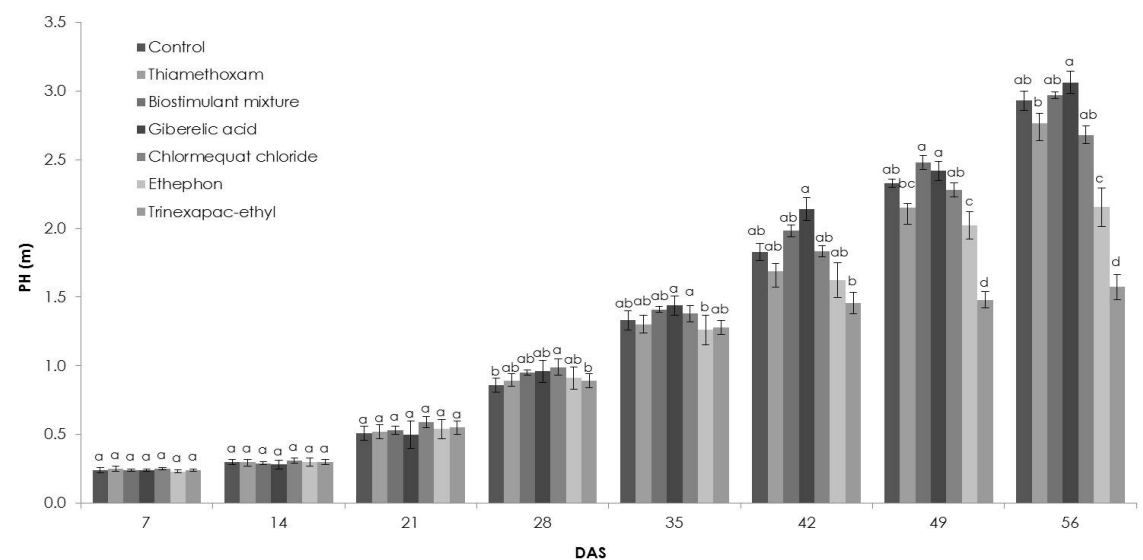

Figure 1. Plant height (PH) of sweet sorghum 'Ceres 81 ' until 56 days after sowing (DAS), submitted to plant growth regulators (PGRs), via foliar spraying. Vertical bars indicate standard errors (SE) $(n=6)$ and letters indicate significant differences at $P<0.01$ (according to Tukey's multiple range test). Piracicaba, SP, Brazil (2011-2012).

Table 1. Means of inflorescence dry matter (IDM), soluble solids (SS), shoot dry matter (SDM), crude protein (CP), ashes, neutral detergent fiber (NDF), and in vitro digestibility (IVD) variables, at 86 days after sowing (DAS), of sweet sorghum 'Ceres 81' submitted to plant growth regulators (PGRs) treatments. Piracicaba, SP, Brazil (2011-2012).

\begin{tabular}{|c|c|c|c|c|c|c|c|}
\hline Treatments & $\mathrm{IDM}(\mathrm{g})$ & $\mathrm{SS}\left({ }^{\circ} \mathrm{Brix}\right)$ & $\begin{array}{l}\mathrm{SDM} \\
\left(\mathrm{g} \mathrm{kg}^{-1}\right)\end{array}$ & $\begin{array}{c}C P \\
\left(g \mathrm{~kg}^{-1} \mathrm{DM}\right)\end{array}$ & $\begin{array}{c}\text { Ashes } \\
\left(\mathrm{g} \mathrm{kg}^{-1} \mathrm{DM}\right)\end{array}$ & $\begin{array}{c}\text { NDF } \\
\left(\mathrm{g} \mathrm{kg}^{-1} \mathrm{DM}\right)\end{array}$ & $\begin{array}{c}\text { IVD } \\
\left(\mathrm{kg}^{-1} \mathrm{DM}\right)\end{array}$ \\
\hline Control & $\begin{array}{l}3.7 \mathrm{ab} \\
(0.1)\end{array}$ & $\begin{array}{l}12.0^{a} \\
(1.0)\end{array}$ & $\begin{array}{l}893.7^{b} \\
(3.1)\end{array}$ & $\begin{array}{c}50.8^{a} \\
(4.6)\end{array}$ & $\begin{array}{c}48.4^{\mathrm{bc}} \\
(1.8)\end{array}$ & $\begin{array}{c}544.7^{a} \\
(8.5)\end{array}$ & $\begin{array}{l}640.8^{a} \\
(14.5)\end{array}$ \\
\hline Thiamethoxam & $\begin{array}{l}3.2^{\mathrm{ab}} \\
(0.1)\end{array}$ & $\begin{array}{l}13.6^{a} \\
(1.0)\end{array}$ & $\begin{array}{c}928.1^{\mathrm{ab}} \\
(23.2)\end{array}$ & $\begin{array}{l}40.8^{a} \\
(4.4)\end{array}$ & $\begin{array}{c}45.6 \mathrm{bc} \\
(1.8)\end{array}$ & $\begin{array}{c}521.0^{\mathrm{ab}} \\
(14.0)\end{array}$ & $\begin{array}{l}554.0^{a} \\
(21.8)\end{array}$ \\
\hline $\begin{array}{l}\text { Biostimulant } \\
\text { mixture }\end{array}$ & $\begin{array}{c}3.3^{a b c} \\
(0.1)\end{array}$ & $\begin{array}{l}10.2^{a} \\
(1.3)\end{array}$ & $\begin{array}{c}934.1^{\mathrm{ab}} \\
(4.9)\end{array}$ & $\begin{array}{l}45.4^{a} \\
(5.3)\end{array}$ & $\begin{array}{l}53.0^{\mathrm{b}} \\
(3.7)^{-}\end{array}$ & $\begin{array}{c}527.1^{\mathrm{ab}} \\
(10.3)\end{array}$ & $\begin{array}{l}628.6^{a} \\
(37.5)\end{array}$ \\
\hline Gibberellic acid & $\begin{array}{l}4.0^{a} \\
(0.1)\end{array}$ & $\begin{array}{l}14.0^{a} \\
(1.1)\end{array}$ & $\begin{array}{c}936.3^{a b} \\
(2.9)\end{array}$ & $\begin{array}{l}40.5^{a} \\
(1.6)\end{array}$ & $\begin{array}{l}42.7^{c} \\
(2.1)\end{array}$ & $\begin{array}{c}528.8^{\mathrm{ab}} \\
(2.7)\end{array}$ & $\begin{array}{l}689.9^{a} \\
(21.7)\end{array}$ \\
\hline $\begin{array}{l}\text { Chlormequat } \\
\text { chloride }\end{array}$ & $\begin{array}{l}2.9 \mathrm{bc} \\
(0.4)\end{array}$ & $\begin{array}{l}13.2^{a} \\
(1.2)\end{array}$ & $\begin{array}{c}946.4^{\mathrm{a}} \\
(1.3)\end{array}$ & $\begin{array}{l}47.9^{a} \\
(4.9)\end{array}$ & $\begin{array}{c}48.8^{b c} \\
(0.4)\end{array}$ & $\begin{array}{c}563.4^{a} \\
(6.5)\end{array}$ & $\begin{array}{l}639.8^{a} \\
(18.1)\end{array}$ \\
\hline Ethephon & $\begin{array}{l}1.4^{d} \\
(0.1)\end{array}$ & $\begin{array}{l}14.0^{a} \\
(0.9)\end{array}$ & $\begin{array}{c}939.4^{\mathrm{ab}} \\
(1.4)\end{array}$ & $\begin{array}{l}41.2^{a} \\
(3.0)\end{array}$ & $\begin{array}{l}54.5^{\mathrm{b}} \\
(0.2)\end{array}$ & $\begin{array}{l}550.4^{a} \\
(11.4)\end{array}$ & $\begin{array}{c}624.1^{a} \\
(8.3)\end{array}$ \\
\hline Trinexapac-ethyl & $\begin{array}{l}2.4 \mathrm{dc} \\
(0.2) \\
\end{array}$ & $\begin{array}{l}14.2^{a} \\
(1.2) \\
\end{array}$ & $\begin{array}{c}926.6^{\mathrm{ab}} \\
(9.4) \\
\end{array}$ & $\begin{array}{c}59.2^{a} \\
(3.1) \\
\end{array}$ & $\begin{array}{l}73.2^{a} \\
(2.0) \\
\end{array}$ & $\begin{array}{c}493.9^{\mathrm{b}} \\
(8.4) \\
\end{array}$ & $\begin{array}{l}671.8^{a} \\
(34.7) \\
\end{array}$ \\
\hline Means & 3.05 & 13.07 & 929.2 & 46.5 & 52.3 & 532.7 & 635.0 \\
\hline C.V. (\%) & $18.43^{*}$ & 21.88 & $1.83^{*}$ & 15.11 & $6.81^{* *}$ & $3.08^{* *}$ & 4.90 \\
\hline
\end{tabular}




\begin{abstract}
Ethephon is an acid (2-chloroethylphosphonic acid) that releases the plant hormone ethylene through its decomposition, which takes place at higher $\mathrm{pH}$ values (Biddle et al., 1976). Among the ethylene effects on plants, we can cite the inhibition of terminal shoot growth, seed germination by dormancy breaking, root initiation promotion, leaf senescence and floral differentiation. This hormone is highly responsive to environmental stresses (Wang et al. 2013). It was observed a reduction of $26 \%$ in $\mathrm{PH}$ due to the ethephon application. This reduction was not as pronounced as that caused by trinexapac-ethyl, which was $46 \%$ in relation to control.
\end{abstract}

Ethephon applied via foliar spraying (480 $\mathrm{g}$ a.i. $\mathrm{ha}^{-1}$ ) showed an inhibitory effect on sugarcane flowering (Caputo et al., 2007). The flowering inhibition could result in reduced carbohydrates sink by inflorescences. It was noticed the significant reduction of IDM by the ethephon application (Table 1). This reduction in IDM with the reduction in $\mathrm{PH}$ allows better quality of sorghum for the ethanol production. As can be observed in Table 1, IDM and $\mathrm{PH}$ reduction did not decrease the SS content in stalks.

The PGRs used in this research altered the contents of SDM, NDF, and ashes, but they did not show any effect on SS, CP, and IVD (Table 1). It can be observed that all PGRs lead to increases in SDM content, but only chlormequat chloride was the product with significant increase effect in SDM, when compared to control (5.9\%). In the case of ashes content, trinexapac-ethyl determined an increase of $51 \%$, whereas NDF was decreased in $9 \%$ by the PGR application (Table 1). The NDF fraction has most components indigestible or not well digested in the rumen, such as cellulose, lignin, hemicellulose and pectin. These results highlight a greater potential of sorghum acceptance by ruminants due to the lower rumen filling with indigestible portion (NDF), improving the feeding efficiency of the animal (Freitas et al., 2006).

None of PGRs applied lead to increases in SS, different from results presented in the literature (Almodares et al., 2011), where these authors report that ethephon alters SS in sweet sorghum cultivars. For $\mathrm{CP}$, it was noted that the PGRs used in this study did not provide any difference when compared to control. However, the CP values observed are consistent with the literature for sorghum plants (Dien et al., 2009; Ayub et al., 2010).

The use of trinexapac-ethyl and chlormequat chloride on sweet sorghum allows adequate plant sizes, facilitating the crop management and harvest process. These studied PGRs also increased the sweet sorghum nutritional quality, making the crop a good alternative for biodiesel production, whereas its residue can be destined to animal feeding.

\section{Acknowledgments}

The authors are grateful to D.Sc. Rosana Aparecida Possenti for providing the laboratory where the nutritional value analysis was performed.

\section{References}

Almodares, A., Taheri, R., Eraghizadeh, F. 2011. The effects of ethephon on biomass and carbohydrate content in two sweet sorghum cultivars. International Journal of Plant Production 6: $279-290$.

Almodares, A., Usofzadeh, M., Daneshvar, M. 2013. Effect of nitrogen and ethephon on growth parameters, carbohydrate contents and bioethanol production from sweet sorghum. Sugar Tech 15: 300-304.

AOAC. 1995. Official methods of analysis of AOAC International. AOAC-Association of Official Analytical Chemists, Washington, USA. $1051 \mathrm{p}$.

Ayub, M., Nadeem, M.A., Tahir, M., Ghafoor, A., Ahmed, Z., Naeem, M. 2010. Comparative studies on the growth, forage yield and quality of sorghum (Sorghum bicolor L.) varieties under irrigated conditions of Faisalabad. Pakistan Journal of Life and Social Sciences 8: 94-97.

Biddle, E., Kerfoot, D.G.S., Kho, Y.H., Russell, K.E. 1976. Kinetic studies of the thermal decomposition of 2-chloroethylphosphonic acid in aqueous solution. Plant Physiology 58: 700-702.

Caputo, M.M., Silva, M.A., Beauclair, E.G.F., Gava, G.J.C. 2007. Acúmulo de sacarose, 
produtividade e florescimento de cana de açúcar sob reguladores vegetais. Interciência 32: 834-840.

Dien, B.S., Sarath, G., Pedersen, J.F., Sattler, S.E., Chen, H., Funnel-Harris, D.L., Nichols, N.N., Cotta, M.A. 2009. Improved sugar conversion and ethanol yield for forage sorghum (Sorghum bicolor L. Moench) lines with reduced lignin contents. BioEnergy Research 2: 153-164.

Freitas, A.W.P, Pereira, J.C., Rocha, F.C., Detmann, E., Barbosa, M.H.P., Ribeiro, M.D., Costa, M.G. 2006. Avaliação da divergência nutricional de genótipos de cana-de-açúcar (Saccharum ssp.). Revista Brasileira de Zootecnia 35: 229-236.

Godsey, C.B., Linneman, J., Bellmer, D., Huhnke, R. 2012. Developing row spacing and planting density recommendations for rainfed sweet sorghum production in the southern plains. Agronomy Journal 104: 280-286.

Leite, G.H.P., Crusciol, C.A.C., Silva, M.A. 2011. Desenvolvimento e produtividade da cana-deaçúcar após aplicação de reguladores vegetais em meio de safra. Semina: Ciências Agrárias 32: 129-138.

Milne, R.J., Byrt, C.S., Patrick, J.W., Grof, C.P.L. 2013. Are sucrose transporter expression profiles linked with patterns of biomass partitioning in Sorghum phenotypes? Frontiers in Plant Science 4: 1-12.

Nakayama, I., Miyazawa, T., Kobayashi, M., Kamiya, Y., Abe, H., Sakurai, A. 1991. Studies on the action of the plant growth regulators $B X$ 112, DOCHC, and DOCHC-Et. In: Takahashi, N., Phinney, O., MacMillan, J. (eds) Gibberellins. Springer-Verlag, New York, 311-319.

Rademacher, W. 2000. Growth retardants: effects on gibberellins biosynthesis and other metabolic pathways. Annual Review of Plant Physioly and Plant Molecular Biology 51: 501-531.

SAS. 2009. SAS/STAT 9.2 User's guide. SAS Institute Inc, Cary, USA. 7886p.

Tilley, J.M.A., Terry, R.A. 1963. A two-stage technique for the in vitro digestion of forage crops. Grass and Forage Science 18: 104-111
Van Soest, P.J. 1994. Nutritional ecology of the ruminant. Cornell University Press, Ithaca, USA. 479p.

Wang, A.Q., Huang, W.J., Niu, J.Q, Liu, M., Yang, L.T., Li, Y.R. 2013. Effects of ethephon on key enzymes of sucrose metabolism in relation to sucrose accumulation in sugarcane. Sugar Tech 15: 177-186.

Whitfield, M.B., Chinn, M.S., Veal, M.W. 2012. Processing of materials derived from sweet sorghum for biobased products. Industrial Crops and Products 37: 362-375.

Yuan, J.S., Tiller, K.H., Al-Ahmad, H., Stewart, N.R., Stewart Jr., C.N. 2008. Plants to power: bioenergy to fuel the future. Trends in Plant Science 13: 421429. 